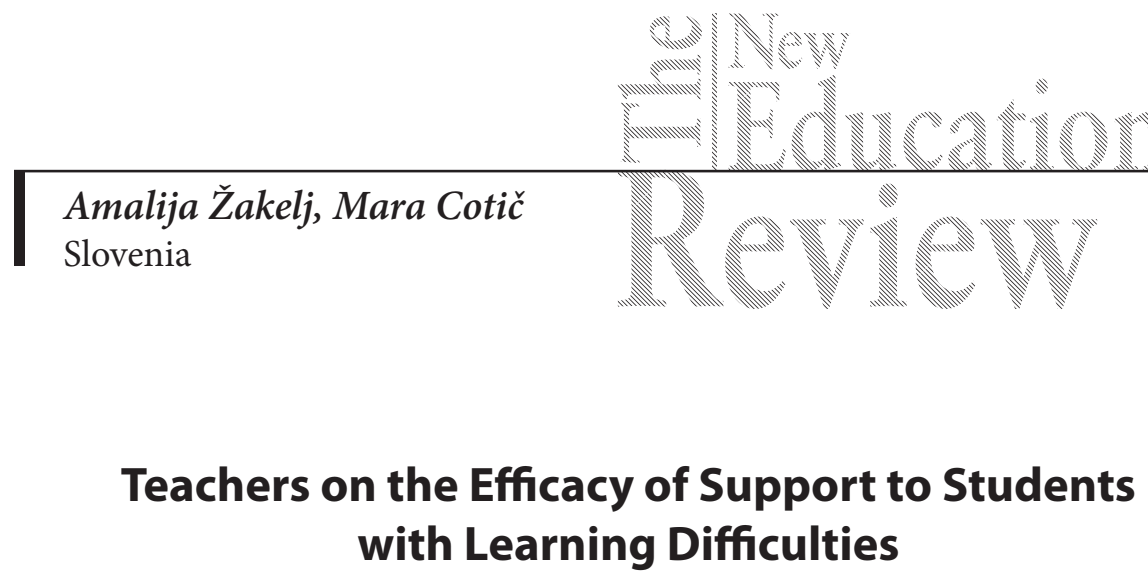

DOI: 10.15804/tner.2016.44.2.15

\begin{abstract}
The empirical study investigated to what extent the implementation of the DPMAT model (a didactic approach to supporting pupils with learning difficulties in mathematics) contributed to the qualification of teachers for the implementation of support to pupils with learning difficulties in mathematics. 80 mathematics teachers and 101 generalist teachers completed a questionnaire through which they rated the impact of the DPMAT model on their knowledge and skills in relation to the teaching and learning of students with difficulties in learning mathematics. The mathematics teachers assessed the contribution of the model to their skills in the selection and design of appropriate teaching aids $(\mathrm{M}=4.1, \mathrm{SD}=0.8)$ and in the recognition and identification of learning difficulties the highest $(\mathrm{M}=4.0, \mathrm{SD}=0.8)$. The generalist teachers assessed the contribution of the model to their skills in facilitating the use of appropriate teaching aids the highest $(\mathrm{M}=4.0, \mathrm{SD}=1.1)$.
\end{abstract}

Keywords: mathematics, learning difficulties, DPMAT model, recognition of learning difficulties, support measures, teachers' competence

\title{
Introduction
}

Magajna (2008) distinguishes between general or non-specific learning difficulties and specific learning difficulties. General or non-specific learning difficulties can originate in the environment (e.g., economic and cultural deprivation, social-emotional deprivation, social-cultural diversity, multilingualism and 
multiculturalism), some internal factors (e.g., generally slowed down development of cognitive abilities, disorders in attention, hyperactivity, below average and limited intellectual abilities) or inappropriate educational interactions (e.g., fear of failure, immaturity, and lack of learning habits). For these reasons individuals may have different problems and obstacles in the acquisition and dissemination of knowledge or skills.

Teachers' ability to support pupils with learning difficulties in mathematics is positively associated with their proficiency in dealing with mathematical content (Hill, 2008), their competence in performing effective didactic and methodological approaches to pupils with learning difficulties, their understanding of teacher and student roles in education, and with their views and conceptions of the importance of specific mathematical content.

Tomlinson (2003) emphasises that while teaching pupils with learning difficulties teachers are expected to use differentiated teaching approaches and to adapt didactic materials to individual differences in pupils' prior knowledge and understanding of mathematics. Paths that follow these objectives include the selection of examples, alternative explanations, and identifying and correcting misconceptions. To achieve these objectives, the teacher, in addition to having sound mathematical and didactic knowledge, must understand the learner's reflection on mathematics (ibid.).

Similarly, Piciga (1995), Ball (1990), and Hill (2008) find in their research that teaching, particularly in primary schools, requires an understanding of the cognitive development of pupils, such as understanding the cognitive abilities of pupils which are required for understanding specific didactic topics, and the knowledge of ways to promote those skills. In addition to the developmental phase of the pupil, the pupil's prior knowledge, the teacher's transmission of new concepts, promotion of processes that occur in mathematical thinking are also important when learning new mathematical concepts (Rugelj, 1996; Žakelj, 2004).

\section{Empirical part}

\section{Research problem}

The purpose of the research project was to develop a didactic approach to supporting pupils with learning difficulties in mathematics (hereinafter: the DPMAT model) and to try it out in practice.

When setting up and designing the DPMAT model we built on the findings of a number of domestic and foreign research studies suggesting that low 
achievement in mathematics is a complex problem (Mullis, 2008). We took into consideration their observations and experiences of working with pupils with learning difficulties, available conceptual starting points for working with pupils with learning difficulties (Chudgar \& Luschei, 2009; Čačinovič Vogrinčič, 2008; Magajna, 2007; Magajna, 2008; Sugman, 2011; Wilkins, 2002), theories of learning, and strategies of working with pupils with learning difficulties.

The conceptual design of the DPMAT model is based on the following principles: giving sense to mathematical knowledge from the perspective of providing assistance to pupils with learning difficulties, classes organised as pupil and teacher mutual activity, as well as the principle of participation.

Different sectors of the DPMAT model are determined in two key content pillars: the first one defines the elements of an encouraging and safe learning environment, and the second determines the methodological steps in implementing modifications for pupils with learning difficulties in mathematics.

The key elements of an encouraging and safe learning environment are: providing expert staff with knowledge about and awareness of learning difficulties of pupils in mathematics, joint creation of instruction and joint creation of mathematics, establishment of an encouraging social environment, mutual cooperation of expert staff, and cooperation with parents. An encouraging and safe learning environment can be created by conscious teachers and by other professional staff familiar with both the characteristics of pupils with learning difficulties and approaches to the implementation of adaptations to pupils with learning difficulties.

The methodological steps of the DPMAT model are circularly connected and spirally upgraded: prior knowledge diagnostics; identification of learning difficulties; planning strategies/measures of support; implementation of appropriate strategies/measures of support; reflection of the teacher and pupil, evaluation of student progress and evaluation of the effectiveness of support.

The plan of treating learning difficulties is an integral part of the teaching DPMAT model. A didactic unit contains a substantive and temporally rounded up whole, in which we plan: continuous and systematic monitoring of pupils' progress (diagnostic, formative, summative); the necessary prior knowledge; general and operational objectives and contents (scope, depth of content, its message); approaches to the identification of learning difficulties in the organization of work, socialization and mathematical contents; measures of help; monitoring the pupil's progress; and evaluation of support measures. We define the necessary didactic situations from the perspective of pupils with learning difficulties. 


\section{Research Focus}

The DPMAT model was designed to support teachers in the implementation of support to pupils with learning difficulties in mathematics; we also tried it out in practice. The empirical study investigated:

1. to what extent the implementation of the DPMAT model contributed to the qualification of teachers for the implementation of support to pupils with learning difficulties in mathematics;

2. whether there are any differences between generalist teachers and teachers of mathematics in assessing the contribution of the model to their qualifications to implement support to pupils with learning difficulties in mathematics.

\section{Research Methodology}

The study included 101 generalist teachers and 80 mathematics teachers from 24 Slovenian basic schools, who in the 2010/11 and 2011/12 school years participated in the project Implementation of adaptations for pupils with learning difficulties in mathematics.

In reference to the first research question, we were interested in how the generalist teachers and the teachers of mathematics assessed the contribution of the DPMAT model to their qualifications for the planning and implementation of appropriate assistance measures to pupils with learning difficulties in mathematics. The effectiveness of the model was evaluated along the items (Table 1, Table 2).

We used a questionnaire, with which the respondents evaluated the contribution of the DPMAT model to their ability to implement forms of assistance to pupils with learning difficulties in mathematics after deployment of the model in practice.

Furthermore, we asked whether there were any differences between the generalist teachers and the mathematics teachers.

The data obtained from the questionnaires were statistically analysed in accordance with the purposes and predictions of the study, using $\mathrm{R}$ tools for Windows. For data processing we used the following methods:

- frequency distribution to show the responses to closed questions and

- Mann Whitney rank sum test to determine the differences between the two groups of teachers: generalist teachers and mathematics teachers. 


\section{Research Results}

\section{Contribution of the DPMAT model to planning the learning process}

Table 1. Contribution of the DPMAT model to planning the learning process

\begin{tabular}{|c|c|c|c|c|c|c|c|}
\hline & Group & $\mathrm{n}$ & M & SD & $\mathrm{R}$ & $\mathrm{W}$ & $\mathrm{p}$ \\
\hline \multirow{2}{*}{$\begin{array}{l}\text { identifying prior knowledge of pupils } \\
\text { with learning difficulties }\end{array}$} & gen.t. & 80 & 3.1 & 1.0 & 57.8 & 1384.5 & \multirow[t]{2}{*}{0.41} \\
\hline & math $\mathrm{t}$. & 38 & 3.3 & 1.0 & 63.1 & & \\
\hline \multirow{2}{*}{$\begin{array}{l}\text { recognition and identification of learning } \\
\text { difficulties }\end{array}$} & gen. t. & 80 & 3.6 & 1.0 & 55.5 & 1201 & \multirow[t]{2}{*}{0.05} \\
\hline & math $\mathrm{t}$. & 38 & 4.0 & 0.8 & 67.9 & & \\
\hline \multirow{2}{*}{$\begin{array}{l}\text { adapting preparations for instruction } \\
\text { (anticipation of learning disabilities) }\end{array}$} & gen.t. & 78 & 3.2 & 1.0 & 54.5 & 1171.5 & \multirow[t]{2}{*}{0.14} \\
\hline & math $\mathrm{t}$. & 36 & 3.6 & 1.0 & 64.0 & & \\
\hline \multirow{2}{*}{$\begin{array}{l}\text { selection and design of appropriate didac- } \\
\text { tic tools }\end{array}$} & gen.t. & 80 & 3.9 & 1.1 & 58.6 & 1444 & \multirow[t]{2}{*}{0.65} \\
\hline & math $\mathrm{t}$. & 38 & 4.1 & 0.8 & 62.5 & & \\
\hline \multirow{2}{*}{$\begin{array}{l}\text { communication with parents of pupils } \\
\text { with learning difficulties }\end{array}$} & gen.t. & 79 & 2.7 & 1.1 & 55.6 & 1232 & \multirow[t]{2}{*}{0.11} \\
\hline & math $\mathrm{t}$. & 38 & 3.1 & 1.1 & 66.1 & & \\
\hline \multirow{2}{*}{$\begin{array}{l}\text { communication with pupils with learning } \\
\text { difficulties }\end{array}$} & gen.t. & 80 & 3.1 & 1.2 & 54.1 & 1088 & \multirow[t]{2}{*}{0.01} \\
\hline & math $\mathrm{t}$. & 38 & 3.7 & 0.9 & 70.9 & & \\
\hline
\end{tabular}

Legend: gen. t. - generalist teacher; math t. - mathematics teacher, $\mathrm{n}$ - the number of teachers; $\mathrm{M}$ - arithmetical mean of the teachers' responses (answers are on a scale of: Respondents replied on a five-point scale: 1 - it didn't contribute at all, 2 - it contributed little, 3 - it contributed averagely, 4 - it contributed a lot, 5 - it contributed very much; SD - standard deviation, $\mathrm{R}$ - average rank; $\mathrm{W}$ - Mann Whitney rank sum test, $\mathrm{p}$ - risk in completing the statistical significance of differences (the difference is statistically significant $-\mathrm{p}<0.05$ )

In planning appropriate assistance measures, the mathematics teachers assessed the highest the contribution of the DPMAT model to their competence in the selection and design of appropriate didactic tools $(M=4.1)$ and in the recognition and identification of learning difficulties $(M=4.0)$. The generalist teachers rated the highest the contribution of the model to the selection and design of appropriate didactic tools $(\mathrm{M}=3.9)$.

Following items: adapting preparations for instruction (mathematics teachers: $M=3.6$, generalist teachers: $M=3.2$ ), identifying prior knowledge of pupils with learning difficulties (mathematics teachers: $\mathrm{M}=3.3: \mathrm{M}=3.1$ ), and communication with pupils with learning difficulties (mathematics teachers: $M=3.7$, generalist teachers: $M=3.1$ ). The contribution of the DPMAT model to the qualification of teachers in communication with the parents of pupils with learning difficulties 
(generalist teachers: $\mathrm{M}=2.7$ mathematics teachers: $\mathrm{M}=3.1$ ) was assessed the lowest.

Somewhat surprising are the lower ratings of the teachers in the model item: identification of prior knowledge of pupils with learning difficulties (generalist teachers: $M=3.1$ and mathematics teachers: $M=3.3$ ), despite a very strong focus of the model exactly on this segment. The reasons for this may be, of course, very different: the teachers' didactic and methodological knowledge, their knowledge on the cognitive development and way of students' thinking, how the teachers understand the important elements of successful learning and the promotion of pupils and the contribution of the model in this area. In reference to the detection of learning difficulties and planning assistance measures, the survey results show that the mathematics teachers assessed the contribution of the model to their skills slightly higher than the generalist teachers, however, there are no statistically significant differences between them, except for the item communication with pupils with learning difficulties (generalist teachers: $\mathrm{M}=2.7$, teachers of mathematics: $\mathrm{M}=3.7 ; \mathrm{p}=0.01$ ).

\section{Contribution of the DPMAT model in the phases of the learning process}

Table 2. Contribution of the DPMAT model in the phases of the learning process

\begin{tabular}{|c|c|c|c|c|c|c|c|}
\hline & Group & $\mathbf{n}$ & M & SD & $\mathrm{R}$ & $\mathrm{W}$ & $\mathrm{p}$ \\
\hline \multirow[t]{2}{*}{ adapting delivery of learning content } & gen.t. & 79 & 3.3 & 1.0 & 55.6 & 1229 & \multirow[t]{2}{*}{0.15} \\
\hline & math $\mathrm{t}$. & 37 & 3.6 & 0.9 & 64.8 & & \\
\hline \multirow{2}{*}{$\begin{array}{l}\text { adapting methods of knowledge consoli- } \\
\text { dation }\end{array}$} & gen. $t$. & 79 & 3.3 & 1.0 & 55.6 & 1234 & \multirow[t]{2}{*}{0.23} \\
\hline & math $\mathrm{t}$. & 36 & 3.6 & 0.8 & 63.2 & & \\
\hline \multirow[t]{2}{*}{ adapting ways of assessment } & gen. $t$. & 78 & 3.5 & 1.1 & 56.3 & 1311 & \multirow[t]{2}{*}{0.41} \\
\hline & math t. & 37 & 3.7 & 0.8 & 61.6 & & \\
\hline \multirow[t]{2}{*}{ adapting learning materials } & gen. $t$. & 78 & 3.4 & 1.1 & 56.3 & 1312.5 & \multirow[t]{2}{*}{0.42} \\
\hline & math $\mathrm{t}$. & 37 & 3.6 & 0.9 & 61.5 & & \\
\hline \multirow{2}{*}{$\begin{array}{l}\text { facilitating the use of appropriate teaching } \\
\text { aids (pocket calculator, numeric tape, etc.) }\end{array}$} & gen.t. & 79 & 4.0 & 1.1 & 60.9 & 1573.5 & \multirow[t]{2}{*}{0.49} \\
\hline & math t. & 37 & 3.9 & 0.9 & 56.5 & & \\
\hline \multirow{2}{*}{$\begin{array}{l}\text { adapting didactic approaches to achieve } \\
\text { basic standards of knowledge }\end{array}$} & gen.t. & 79 & 3.4 & 1.0 & 55.5 & 1227.5 & \multirow[t]{2}{*}{0.09} \\
\hline & math t. & 38 & 3.7 & 0.7 & 66.2 & & \\
\hline \multirow{2}{*}{$\begin{array}{l}\text { adapting didactic approaches to achieve } \\
\text { minimum standards of knowledge }\end{array}$} & gen.t. & 80 & 3.4 & 1.0 & 56.1 & 1246 & \multirow[t]{2}{*}{0.10} \\
\hline & math t. & 38 & 3.8 & 0.8 & 66.7 & & \\
\hline
\end{tabular}




\begin{tabular}{|c|c|c|c|c|c|c|c|}
\hline & Group & n & M & SD & $\mathrm{R}$ & W & $\mathrm{p}$ \\
\hline \multirow[t]{2}{*}{ implementation of internal differentiation } & gen. t. & 80 & 3.2 & 1.0 & 58.1 & 1406 & \multirow[t]{2}{*}{0.48} \\
\hline & math $\mathrm{t}$. & 38 & 3.3 & 0.9 & 62.5 & & \\
\hline \multirow{2}{*}{$\begin{array}{l}\text { modifying learning environment (seating } \\
\text { order, quiet corner, etc.) }\end{array}$} & gen.t. & 78 & 2.9 & 1.2 & 55.2 & 1221 & \multirow[t]{2}{*}{0.25} \\
\hline & math t. & 36 & 3.1 & 1.1 & 62.6 & & \\
\hline
\end{tabular}

Legend: gen. t. - class teacher; math t. - mathematics teacher, $\mathrm{n}$ - the number of teachers; $\mathrm{M}$ - arithmetical mean of the teachers' responses (answers are on a scale of: 1 - it didn't contribute at all, 2 - it contributed little, 3 - it contributed averagely, 4 - it contributed a lot, 5 - it contributed very much; $\mathrm{SD}$ - standard deviation, $\mathrm{R}$ - average rank; $\mathrm{W}$ - Mann Whitney rank sum test, $\mathrm{p}$ - risk in completing the statistical significance of differences (the difference is statistically significant $-\mathrm{p}<0.05$ )

In the implementation of support measures, the mathematics teachers assessed the highest the contribution of the model in the following items: facilitating the use of appropriate teaching aids $(\mathrm{M}=3.9)$ and adapting didactic approaches to achieve minimum standards of knowledge $(\mathrm{M}=3.8)$. The generalist teachers rated the highest the contribution of the model in the following items: facilitating the use of appropriate teaching aids $(\mathrm{M}=4.0)$ and adapting ways of assessment $(\mathrm{M}=3.5)$.

Following items: adapting ways of assessment (mathematics teachers: $M=3.7$ ), adapting learning materials (mathematics teachers: $\mathrm{M}=3.6$, generalist teachers: $M=3.4$ ), adapting delivery of learning content (mathematics teachers: $M=3.6$, generalist teachers: $M=3.3$ ), adapting methods of knowledge consolidation (mathematics teachers: $\mathrm{M}=3.6$, generalist teachers: $\mathrm{M}=3.3$ ), adapting didactic approaches to achieve basic standards of knowledge (generalist teachers: $\mathrm{M}=3.4$ mathematics teachers: $M=3.7)$, adapting didactic approaches to achieve minimum standards of knowledge (generalist teachers: $\mathrm{M}=3.4$ ), and implementation of internal differentiation (generalist teachers: $M=3.2$ mathematics teachers: $\mathrm{M}=3.3$ ).

The survey results highlight the need for further education of teachers in the field of teaching approaches to determining students' prior knowledge, the cognitive development of pupils, their cognitive abilities that are necessary to understand specific contents, identifying and eliminating the causes of learning difficulties, etc.

In the area of the implementation of the forms of assistance, the teachers ranked the highest the contribution of the model to their skills in facilitating the use of appropriate teaching aids, and in adapting the methods of testing and knowledge assessment. This methodological approach to teaching and learning mathematics is given a lot of attention in Slovenian schools in general, both at the level of 
teacher education and training as well as in the classroom, in direct implementation. In connection with these findings, the survey results show that the effects of individual projects, models, updating the learning process are more effective if complemented with other activities that are complementary and mutually effectively reinforcing the improvement of school practice or lessons.

\section{Conclusion}

The survey results show that both the generalist teachers and mathematics teachers are relatively unanimous in determining in which items the model contributed the most to their ability to apply support measures to pupils with learning difficulties. Both groups (Table 1, Table 2) rated the highest the contribution of the model to their ability to implement support measures in the selection and design of adequate didactic tools, facilitating the use of appropriate teaching aids (pocket calculator, numeric tape, etc.), even though they already use them frequently in practice (Žakelj, 2013) and that they feel very well qualified in this area (ibid.). It is obvious that the use of didactic tools in mathematics in school practice is quite present. Bone \& Colja (2009) emphasize that it is not enough just to use them in the classroom, but it is important that teaching aids are produced and later actively used by pupils themselves. The National Mathematics Advisory Panel (2008) indicates that the potentials for significant impact increase if pupils continue the activities chosen in school also at home, with the assistance of and in cooperation with parents. Unfortunately, both the generalist teachers and the mathematics teachers evaluated the lowest the contribution of the model to their ability to implement support in communication with the parents of pupils with learning difficulties.

In the field of detection of learning difficulties and planning assistance measures, the results of the research show that the mathematics teachers evaluated the contribution of the model to their competence slightly higher than the generalist teachers in all items, but there are no statistically significant differences between them, except in the item communication with pupils with learning difficulties (generalist teachers: $\mathrm{M}=3.1$, mathematics teachers: $\mathrm{M}=3.7, \mathrm{p}=0.01$ ). Where should we look for the reasons for this? Partly, we may find the answer in the survey results (Žakelj, 2013), in which the author found that the generalist teachers estimated significantly higher their ability to detect learning difficulties and plan appropriate assistance measures than the mathematics teachers. Basically, the mathematics teachers estimated their own ability to work with pupils with learn- 
ing difficulties lower, so we can assume that the model gave them an opportunity for further professional development.

It is somewhat surprising that the teachers rated low the item model: identification of prior knowledge of pupils with learning difficulties (generalist teachers: $\mathrm{M}=3.1$, teachers of mathematics: $M=3.3$ ), despite a very strong emphasis on that segment in the model. In implementing the DPMAT model many items include processes of determining prior knowledge of pupils with learning difficulties, however, the teachers' assessment indicates that they have not yet completely adopted this and that more research work with teachers should be carried out in this segment. The reasons are varied: from the teachers' didactic methodological background knowledge, their knowledge of cognitive development and pupils' way of thinking, how the teachers understand important elements for successful learning and progress of pupils, as well as students' and teachers' attitudes towards mathematics, etc. More broadly, however, Schollaert (2006) points out that modernisation of school practices is successful only when the two levels take place side by side: the preparation of theoretical models for modernisation, preparation of various didactic materials for the implementation of change and the introduction of innovations into practice: teacher training, monitoring school practices, promoting the development and school management teams, monitoring the effectiveness of teaching materials and various teaching approaches in practice. In reference to the abovementioned, teachers need time. Often teachers adopt innovations gradually and reluctantly; and the effects of training and development projects are, of course, not immediate, and important trends are usually associated with a cumulative impact of several factors.

The results of the presented study highlight the need for further education of teachers in the area of methodological approaches to identifying pupils' prior knowledge, the cognitive development of pupils, their mental abilities that are necessary to understand specific contents, and detecting and eliminating the causes of learning difficulties, etc.

We can conclude that the results of the research report the effects of the model on the competence of teachers to work with pupils with learning difficulties, but in the background they suggest some other dimensions of teaching mathematics, like, e.g., teachers' attitude towards the implementation of various methodological approaches to teaching and learning; they raise new research questions and initiatives that are linked to teachers' collaboration with parents, methodological approaches to teaching and learning at the level of identification of pupils' prior knowledge, in the identification and elimination of causes of learning difficulties, and in designing the model for effective communication regarding pupils' learning difficulties, etc. 


\section{Acknowledgement}

This paper is a result of the research "Support to teachers in implementing adaptation into pupils with learning difficulties in mathematics", done by the Institute of Education of the Republic of Slovenia (2010-2012), in collaboration with 24 primary schools in the Republic of Slovenia and with the financial support of the Ministry of Education, Science and Sport of the Republic of Slovenia. We would like to extend our heartfelt thanks to all the teachers and head teachers of the participating schools for their constructive cooperation.

\section{References}

Ball, D.L. (1990). The mathematical understandings that prospective teachers bring to teacher education. The Elementary School Journal. 90(4): 449-466.

Bone, J., Colja, N. (2009). Uporaba številskega traku pri pouku matematike v luči fleksibilnega predmetnika. In: Razpet, N. (ed.), Od 0 do neskončnosti: jubilejni zbornik ob 60-letnici Društva matematikov, fizikov in astronomov Slovenije. Ljubljana: DMFA, str. 109.

Chudgar, A., Luschei, T.F. (2009). National Income Inequality and the Importance of Schools: A Hierarchical Cross-National Comparison. American Educational Research Journal; (46)3: 626-658.

Čačinovič Vogrinčič, G. (2008). Soustvarjanje v šoli: učenje kot pogovor. Ljubljana: Ministrstvo za šolstvo in šport, Zavod RS za šolstvo.

Hill, H.C., Blunk, M.L., Charalambous C.Y., Lewis J.M., Phelps G.C., Sleep L. (2008). Mathematical knowledge for teaching and the mathematical quality of instruction: An exploratory study. Cognition and Instruction; 26(4): 430-511.

Magajna, L., Kavkler, M., Čačinovič Vogrinčič G., Pečjak S., Bregar Golobič, K. (2007). Koncept dela: učne težave v osnovni šoli. Ljubljana: Ministrstvo za šolstvo in šport, Urad za razvoj šolstva.

Magajna, L., Pečjak, S., Pekla, J.C., Čačinovič Vogrinčič, G., Bregar Golobič, K., Kavkler, M., Tancig, S. (2008). Učne težave v osnovni šoli. Problemi, perspektive, priporočila. Ljubljana: Zavod RS za šolstvo.

National Mathematics Advisory Panel. (2008). Foundations for Success: The Final Report of the National Mathematics Advisory Panel. Washington (DC): US Department of Education.

Mullis, I.V., Martin, M.O., Foy, P. (2008). TIMSS 2007 International Mathematics Report: Findings from IEA's Trends in International Mathematics and Science Study at the Fourth and Eighth Grades. Chestnut Hill (MA): Boston College, TIMSS and PIRLS International Study Center.

Piciga, D. (1995). Od razvojne psihologije k drugačenmu učenju in poučevanju. Nova Gorica: Educa.

Rugelj, M. (1996). Konstrukcija novih matematičnih pojmov. Doktorsko delo. Ljubljana: Filozofska fakulteta. 
Schollaert, R. (2006). Pomen sprememb v izobraževanju. In: Vpeljevanje sprememb v šole - konceptualni vidik. Zavod RS za šolstvo. Ljubljana.

Sugman, B.L., ed. (2011). Učenci z učnimi težavami, Izvirni delovni projekt pomoči. Ljubljana: Ministrstvo za šolstvo in šport, Fakulteta za socialno delo.

Tomlinson, C.A. (2003). "Differentiating instruction for academic diversity". In: J.M. Cooper (ed.), Classroom teaching skills. $7^{\text {th }}$ ed. Boston: Houghton Mifflin, pp. 149-180.

Wilkins, J.L., Zembylas, M., Travers, K.J. (2002). Investigating correlates of mathematics and science literacy in the final year of secondary school. In: Robitaille DF, Beaton AE, ed. Secondary analysis of the TIMSS data. Boston: Kluwer Academic Publishers. pp. 291-316.

Žakelj, A. (2004). Procesno-didaktični pristop in razumevanje matematičnih pojmov v osnovni šoli. Doktorska disertacija. Filozofska fakulteta Ljubljana.

Žakelj, A. (2013). Pristopi učiteljev pri oblikah pomoči učencem z učnimi težavami pri matematiki $=$ Teaching strategies for helping students with difficulties in learning mathematics. Revija za elementarno izobraževanje, ISSN 1855-4431, Apr. 2013, year. 6, No. 1, pp. 5-25, Tables. 